\title{
Experimental models of autoimmune inflammatory ocular diseases
}

\author{
Modelos experimentais para o estudo de doenças inflamatórias oculares autoimunes
}

\author{
Fabio Gasparin ${ }^{1}$, Beatriz Sayuri Takahashi ${ }^{1}$, Mariana Ramos Scolari ${ }^{2}$, Filipe Gasparin ${ }^{3}$, Lycia Sampalo Pedral ${ }^{4}$, Francisco Max Damico
}

\begin{abstract}
Ocular inflammation is one of the leading causes of blindness and loss of vision Human uveitis is a complex and heterogeneous group of diseases characterized by inflammation of intraocular tissues. The eye may be the only organ involved or uveitis may be part of a systemic disease. A significant number of cases are of unknown etiology and are labeled idiopathic. Animal models have been developed to the study of the physiopathogenesis of autoimmune uveitis due to the difficulty in obtaining human eye inflamed tissues for experiments. Most of those models are induced by injection of specific photoreceptors proteins (e.g., S-antigen, interphotoreceptor retinoid-binding protein, rhodopsin, recoverin, phosducin). Non-retinal antigens, including melanin-associated proteins and myelin basic protein, are also good inducers of uveitis in animals. Understanding the basic mechanisms and pathogenesis of autoimmune ocular diseases are essential for the development of new treatment approaches and therapeutic agents. The present review describes the main experimental models of autoimmune ocular inflammatory diseases.
\end{abstract}

Keywords: Animal models; Uveitis/etiology; Autoimmune diseases; Inflammation

\section{RESUMO}

A inflamação ocular é uma das principais causas de perda visual e cegueira. As uveítes constituem um grupo complexo e heterogêneo de doenças caracterizadas por inflamação dos tecidos intraoculares. O olho pode ser o único órgão envolvido ou a uveíte pode ser parte de uma doença sistêmica. A etiologia é desconhecida em um número significativo de casos, que são considerados idiopáticos. Modelos animais têm sido desenvolvidos para estudar a fisiopatogênese da uveíte autoimune devido às dificuldades na obtenção de tecidos de olhos humanos inflamados para experimentos. Na maioria desses modelos, que simulam as uveítes autoimunes em humanos, a uveíte é induzida com proteínas específicas de fotorreceptores (antígeno-S, proteína ligadora de retinoide do interfotoreceptor, rodopsina, recoverina e fosducina). Antígenos não retinianos, como proteínas associadas à melanina e proteína básica de mielina, são também bons indutores de uveíte em animais. Entender os mecanismos básicos e a patogênese dessas doenças oculares é essencial para o desenvolvimento de novas formas de tratamento das uveítes autoimunes e de novos agentes terapêuticos. Nesta revisão serão abordados os principais modelos experimentais utilizados para o estudo de doenças inflamatórias oculares autoimunes.

Descritores: Modelos animais; Uveítes/etiologia; Doenças autoimunes; Inflamação

\section{INTRODUCTION}

The first descriptions of ocular inflammation date back to 1500 BC (Ebers's papyrus) ${ }^{(1)}$. The term uveitis was first used to characterize any type of intraocular inflammation with non-infectious etiology. Autoimmune uveitis is a constant challenge for researchers due to its variable clinical presentation, evolution, recurrence rates, and etiology, which is still not completely understood.

Uveitis is classified as autoimmune according to clinical criteria(2) Basically, non-infectious intraocular inflammation that presents good response to anti-inflammatory drugs is classified as autoimmune. In some cases, an association with major histocompatibility complex (MHC) molecules can be found.

In order to understand the pathophysiology of autoimmune uveitis and develop new therapies, it is important to identify the possible antigens involved in the disease. The use of experimental models is important as there are many difficulties involved in getting intraocular tissue from patients' eyes, including technical and ethical issues. Experimental models are important for the development of new therapeutic agents as they are useful to evaluate the efficacy and toxicity of systemic and intravitreous drug delivery, such as antibiotics ${ }^{(3-5)}$, corticosteroids ${ }^{(6,7)}$, immunosuppressive drugs ${ }^{(8,9)}$, and more recently
anti-VEGF(10,11), and biological agents (e.g., tacrolimus, sirolimus, etanercept, infliximab, adalimumab, and rituximab) $)^{(12-19)}$.

The aim of this paper is to review the most used experimental autoimmune ocular inflammatory diseases models used in Ophthalmology and their most important aspects.

\section{MODELS OF AUTOIMMUNE OCULAR DISEASE AND OCULAR INFLAMMATION}

In the past 50 years, several experimental models of non-infectious ocular inflammation have been described ${ }^{(20-25)}$. Different parts of the eye of the animal model can become inflamed, simulating the different types of uveitis humans. The most used model is the experimental autoimmune uveitis (EAU). Inflammation can be induced by retinal antigens, such as S-antigen and the interphotoreceptor retinoid-binding protein (IRBP), but other non-retinal antigens and non-ocular antigens can also be used, as bacterial endotoxin and cytokines.

Animal models are very heterogeneous in terms of inflammatory response. Even animals of the same species do not respond the same way to the same antigen, so the information obtained from each of
Funding: No specific financial support was available for this study. Disclosure of potential conflicts of interest: F.Gasparin, None; B.S.Takahashi, None; M.R.Scolari, None; F.Gasparin, None; L.S.Pedral, None; F.M.Damico, None.

Correspondence address: Fabio Gasparin. Av. Princesa Izabel, 274 - apto. 201 - Uberlândia - MG 38400-192 - Brazil - E-mail: fgasparin@usp.br 
the available models are complementary(25). Table 1 shows the most used models for the study of autoimmune ocular inflammatory diseases.

\section{Experimental aUtoimmune UVeitis (EAU)}

EAU is the most used model for the study of autoimmune ocular inflammation, especially in the posterior segment. It is induced by the subcutaneous injection of a single dose of soluble retinal antigen ${ }^{(21,26)}$. The EAU clinical and pathological characteristics depend on the species and the antigen used for induction, but T-cell mediated inflammatory response is always present, mainly CD4+ cells. CD4+ cells recognize antigens presented by antigen presenting cells (APC) in the context of class II main histocompatibility complex (MHC) molecules. Pro-inflammatory cytokines, such as IL-2, IFN- $\boldsymbol{\gamma}$, and TNF- $\alpha$ are produced by the subset Th1 and are important mediators of the cellular immune response ${ }^{(27)}$.

\subsection{S-Antigen}

The S-antigen, also called S-arrestin, is a photoreceptor protein present in abundance in photoreceptors and pineal gland cells $s^{(21)}$. It plays a physiological role in desensitization of the photoactivated transduction cascade by inhibiting coupling of rhodopsin to transducin. In addition, S-antigen is highly antigenic and is a potent inducer of autoimmune uveoretinitis in animals.

EAU is induced by the subcutaneous injection of bovine S-antigen along with the complete Freund's adjuvant (CFA) as vehicle ${ }^{(28)}$. The inflammatory response begins between 10 days and 2 months and lasts from few days to 1 year, depending on the species and the dose of the antigen. In Lewis rats, the inflammation is acute and selflimited but it causes important damage to the retina and choroid within few days ${ }^{(29)}$. The disease is less severe and subacute in other rat strains, guinea pigs, and monkeys. In the latter, the disease may present a longer course with progressive destruction of the retina ${ }^{(29)}$.

Each antigen has a group of antigenic determinants called epitopes. Epitopes are sequences of amino acids that elicit inflammatory response after recognition by the immune system. Some antigens may present various different epitopes, or the same epitopes may be present more than once in the same protein. Peptide $M$ is an 18-amino acid component of S-antigen that has been shown to be highly uveitopathogenic in different species, such as rats, guinea pigs, and monkeys, producing inflammatory changes in eyes very similar to those induced by native $S$-antigen ${ }^{(30)}$. In humans, the amino acids sequence of the S-antigen corresponding to peptide $\mathrm{M}$ was found to be virtually identical to that of the bovine S-antigen(31).

Immunological mimicry between host and microbial proteins has been suggested as a potential mechanism in the development of uveitis in humans. Cross-reactivity between anti-streptococcal monoclonal antibodies with retinal S-antigen from rods of the human eye human eye has been demonstrated, suggesting that both molecules share epitopes of antigenic similarity. These findings may suggest a possible association between host and microbial proteins, which may be a potential mechanism in the development of human uveitis ${ }^{(32)}$.

\subsection{Interphotoreceptor retinoid-binding protein}

IRBP is a protein found primarily between the retinal pigment epithelium (RPE) and the photoreceptor cells. It plays a role in the transport of the retinoids, a product of vitamin A, between the retina and the RPE cells ${ }^{(33,34)}$. Uveitis is induced by subcutaneous injection of isolated bovine IRPB or part of bovine IRPB associated to pertussis toxin with CFA as vehicle ${ }^{(35)}$. IRBP is a strong uveitis inducer in rats ${ }^{(36)}$, monkeys ${ }^{(37)}$, rabbits ${ }^{(38)}$, and mice ${ }^{(22)}$. However, it is a weak inducer in guinea pigs ${ }^{(39)}$. The clinical course and severity of EAU depend on the antigen dosage, the animal species, and the association of pertussis toxin at the moment of induction. In Lewis rats, the acute inflammation may be severe and begin from 8 to 12 days after immunization, lasting 5 to 10 days ${ }^{(36)}$. In mice, uveitis has longer incubation and lasts longer. Mild anterior uveitis may be present and the prominent retinal findings are vasculitis, granuloma, serous detachment, and loss of photoreceptors. Other findings include sub-RPE infiltrates (clinical equivalent of Dallen-Fuchs nodules) and thickening of the choroid and ciliary body ${ }^{(40)}$.

IRBP molecule has 1,264 amino acids, forming 4 repeated units of 300 amino acids each. Each unit presents an uveitogenic site. The peptide 1117-1191 of bovine IRBP is capable of generating important uveal inflammation ${ }^{(41,42)}$. Another study suggests that the rat IRBP peptide $273-283$ also elicits severe uveitis ${ }^{(43)}$. Approximately $84 \%$ of the bovine and human IRBP present identical sequence of amino acids ${ }^{(44,45)}$. Many studies using EAU models induced by IRBP have aimed the identification of the exact immunogenic epitopes ${ }^{(46-48)}$ and interactions with the MHC molecules. Specific IRBP epitopes have already been recognized as uveitogenic in susceptible mice strains: Peptide 1-20 for C57BL/6, 161-180 for B10.RIII, and 201-216 for $B 10 . A^{(49)}$, and recent studies revealed several additional uveitogenic epitopes of human IRBP molecule that elicit EAU in mice ${ }^{(48)}$.

\section{EXPERIMENTAL MELANIN PROTEIN-INDUCED UVEITIS (EMIU)}

Non-soluble melanin proteins isolated from pigmented bovine eye tissues can induce an uveitis model named EMIU(50,51). According to Matteson et al. ${ }^{(52)}$, this model can be induced by subcutaneous injection of melanin proteins in association with Hunter adjuvant.

CD4+ $T$ cells are the primary mediators of the inflammatory response, as well as in EAU ${ }^{(53)}$, but the target tissue is the uvea, where the melanocytes are located, not the retina. Therefore, ocular inflammation is mostly evident in the iris, ciliary body, and choroid. Clinical manifestations begin 10 to 14 days after induction and consists of conjunctival hyperemia, corneal edema, anterior uveitis, iris vessels dilation, hypopyon, and synechiae ${ }^{(40)}$. The 2 -week acute uveitis may present spontaneous recurrences as observed in EAU in mice ${ }^{(54)}$.

Table 1. Comparison among animal models for the study of autoimmune uveitis

\begin{tabular}{lccc}
\hline Model & Antigen & Target & Clinical relevance \\
\hline Experimental autoimmune uveitis (EAU) & S-Antigen & Photoreceptors & Posterior uveitis \\
& IRBP & \\
& Rodpsin \\
& Recoverin & & \\
& Phosducin & & \\
Experimental melanin protein-induced & Melanin protein & Uveal melanocytes & Anterior uveitis \\
uveitis (EMIU) & & & Posterior uveitis \\
& & Difuse uveitis \\
Encephalitis associated uveitis (EAE/AU) & Mielin binding protein & Iris myelinated nerves & Anterior uveitis \\
& & and spinal cord & Multiple sclerosis \\
\hline
\end{tabular}


Histologically, ocular inflammation is characterized by the presence of macrophages and lymphocytes. Except on severe and recurrent cases, the RPE, retina, and optic nerve are rarely involved, even though they can be affected when low dose endotoxins are added $^{(55)}$

IL-2 and IFN- $\gamma$ are the predominant intraocular cytokines produced early in the disease, then IL-12, and finally TNF- $\alpha$ at the peak of the inflammation. Other inflammatory mediators such as nitric oxide are also involved in the inflammatory response ${ }^{(40,52)}$.

Yamaki et al. described the induction of uveoretinitis in rats by peptides derived from tyrosinase, a melanocyte differentiation protein ${ }^{(56,57)}$. After immunization, animals develop uveitis, cutaneous vitiligo, and meningitis, a disease similar to Vogt-Koyanagi-Harada $(\mathrm{VKH})$ disease in humans. Damico et al. have shown the importance of peptides derived from human melanocyte differentiation proteins on the pathogenesis of VKH disease in humans, reinforcing the important role of melanin proteins in the pathogenesis of certain autoimmune uveitis ${ }^{(58)}$.

\section{EXPERIMENTAL AUTOIMMUNE ENCEPHALITIS ASSOCIATED tO ANTERIOR UVEITIS (EAE/AU)}

This experimental model is characterized by relapsing anterior uveitis associated to encephalitis. Myelin basic protein (MBP) induces inflammation in rats eyes after subcutaneous injection associated to $\mathrm{CFA}^{(59)}$.

MBP is highly expressed in the peripheral nervous fibers and in the central nervous system. This protein is produced by myelinated cells from the iris nerves and oligodendrocytes, and these cells may be the target of the autoantigens in multiple sclerosis associated uveitis $^{(40)}$

Ten to 12 days after immunization, eyes present with iris vessel dilation, anterior uveitis, hypopyon, and synechia, which persist for about 30 days ${ }^{(60)}$. Inflammation severity depends on the species susceptibility, myelin quantity in each animal, and MBP dose ${ }^{(25)}$. If severe, the inflammation affects the posterior segment, with optic nerve inflammation. Encephalitis and uveitis usually begin at the same time, but uveitis has longer duration and uveitis is still ongoing even after the encephalitis resolves ${ }^{(61,62)}$. IL-2 and IFN- $\gamma$ produced by Th1 cells are the major inflammatory mediators present in this animal model.

Even though the mechanisms for anterior uveitis relapses are not well known, studies suggest that MBP minor epitopes are involved in the relapses by expansion of the sensitized T cell $^{(63)}$. In Lewis rats, inflammatory recurrences are related to some specific MBP epitopes, specifically peptides $100-120,121-141$, and $142-67^{(64)}$. This relapsing anterior uveitis model is especially important for the study of some types of auto-immune uveitis in humans, which are usually recurrent in nature.

\section{Non-ocular antigen mediated UVEITIS}

Some experimental uveitis models can be induced by non-ocular antigens, mainly bacterial endotoxins. Endotoxin-induced uveitis (EIU) can be induced by intravenous, intraperitoneal, or subcutaneous injection of low doses of endotoxins, such as E. coli lipopolysaccharide $(\mathrm{LPS})^{(64)}$. LPS is an important component of the outer membrane of Gram-negative bacteria, contributing to the structural integrity and helping to stabilize its membrane structure. LPS induces a severe immune response in animals.

In the rats, ocular inflammatory signs appear few hours after LPS injection and may spontaneously resolve within few days. Repeated injections of LPS seem to result in a state of tolerance and the animals no longer develop uveitis(65).

Anterior uveitis in Lewis rats can also be induced only by the injection of CFA in around 22\% of cases. When Mycobacterium butyricum is added, the uveitis incidence rises to $50 \%$ or more ${ }^{(66)}$.
The intraocular injections of some cytokines, such as IL-1, IL-6, IL-8, and TNF-a, can also be used to induce uveitis in experimental models ${ }^{(67,68)}$. New discoveries on the role of cytokines in ocular inflammation, as well as clinical results of cytokine-blocking agents, have been made using transgenic animals, which can overexpress or do not express the citokines genes.

\section{NeW MOdels Of EXPERIMENTAL AUtoimmune UVEITIS}

A particular EAU model can be induced in transgenic mice. These animals do not express MHC molecules. Instead, they present the hu-

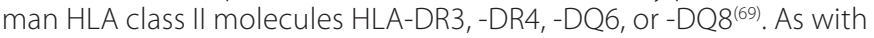
the parental strain C57BL/10, these transgenic mice develop uveitis when immunized with IRBP. However, unlike the parental strain, they also develop uveitis when in contact with S-antigen ${ }^{(70)}$. This humanized EAU model supports the notion that responses to S-antigen drive uveitis in humans and may help to identify additional uveitogenic peptides presented by specific HLA molecules ${ }^{(49)}$.

Transgenic mice that express two human HLA alleles, such as DR3 and DQ6, have been shown to be more susceptible than mice that express only one allele. This suggests that there are complementing influences between different HLA molecules, and it is possible that some alleles combinations may play a protective role ${ }^{(49)}$.

Another model of EAU can be induced by IRBP peptides associated to dendritic cells (DC). Dendritic cells are APCs and probably the main ones capable of stimulating immature $T$ cells ${ }^{(49)}$. This model can be induced by the infusion of DC, matured in vitro with LPS and anti-CD40, and pulsed with IRBP peptide $161-180^{(71)}$. This EAU model differs in immunological, clinical, and pathological characteristics from the traditional IRBP-CFA model, in which the disease is shorter and less severe. The fundus lesions are punctates and there are more neutrophils than monocytes ${ }^{(48)}$. This autoimmune uveitis model demonstrates that the same antigen may induce different forms of uveitis, depending on how they are presented to the immune system, and may help to explain the heterogeneity of human uveitis ${ }^{(48)}$.

\section{CONCLUSION}

Researches on experimental models have been important to explain the pathophysiological mechanisms involved in different ocular autoimmune inflammatory diseases. EAU is one of the most used animal models. After immunization with uveitogenic antigens, animals develop an immune response mediated primarily by CD4+ $T$ cells. Clinical findings are somewhat similar to some human autoimmune uveitis. Even though these models contribute for a better understanding of the pathophysiology of autoimmune uveitis in humans, there are still many questions to be answered, such as triggers, recurrences, and individual susceptibility. Heterogeneous clinical findings may be related to the observation that each subject may respond to more than one epitope per antigen and respond differently to each one of them, depending on how it is presented and how it is recognized by the immune system.

Lately, new ocular inflammatory experimental models have been available due to the advances in genetics and molecular engineering. These models may help the development of news therapies, with more specific and efficient drugs, avoiding side effects. In addition, animal models are important for the study of new routes of drug delivery, especially by intravitreal injection.

\section{REFERENCES}

1. Meira DM, Rocha ML, Oréfice F. Conceito e classificação das uveítes. In: Oréfice F, editor. Uveíte clínica e cirúrgica. 2a ed. Rio de Janeiro: Cultura Médica; 2005. p.18-20.

2. Nussenblatt RB, Whitcup SM. Uveitis: fundamentals and clinical practice. $3^{\text {rd }}$ ed. Philadelphia: Mosby Elsevier; 2003.

3. Peyman GA, May DR, Ericson ES, Apple D. Intraocular injection of gentamicin. Toxic effects of clearance. Arch Ophthalmol. 1974;92(1):42-7.

4. Peyman GA, Herbst R. Bacterial endophthalmitis. Treatment with intraocular injection of gentamicin and dexamethasone. Arch Ophthalmol. 1974;91(5):416-8. 
5. D’Amico DJ, Caspers-Velu L, Libert J, Shanks E, Schrooyen M, Hanninen LA, Kenyon KR. Comparative toxicity of intravitreal aminoglycoside antibiotics. Am J Ophthalmol. 1985;100(2):264-75

6. Kwak HW, D'Amico DJ. Evaluation of the retinal toxicity and pharmacokinetics of dexamethasone after intravitreal injection. Arch Ophthalmol. 1992;110(2):259-66. Comment in Arch Ophthalmol. 1993;111(1):20-1.

7. Yu SY, Damico FM, Viola F, D'Amico DJ, Young LH. Retinal toxicity of intravitreal triamcinolone acetonide: a morphological study. Retina. 2006;26(5):531-6.

8. Velez G, Yuan P, Sung C, Tansey G, Reed GF, Chan CC, et al. Pharmacokinetics and toxicity of intravitreal chemotherapy for primary intraocular lymphoma. Arch Ophthalmol. 2001;119(10):1518-24

9. Grisolano J Jr, Peyman GA. Retinal toxicity study of intravitreal cyclosporin. Ophthalmic Surg. 1986;17(3):155-6.

10. Manzano RP, Peyman GA, Khan P, Kivilcim M. Testing intravitreal toxicity of bevacizumab (Avastin). Retina. 2006;26(3):257-61.

11. Bakri SJ, Cameron JD, McCannel CA, Pulido JS, Marler RJ. Absence of histologic retinal toxicity of intravitreal bevacizumab in a rabbit model. Am J Ophthalmol. 2006; 142(1):162-4.

12. Passos E, Genaidy MM, Peyman GA. Ocular toxicity of intravitreal tacrolimus. Ophthalmic Surg Lasers. 2002;33(2):140-4.

13. Manzano RP, Peyman GA, Khan P, Kivilcim M, Chevez-Barrios P, Takahashi W. Testing intravitreal toxicity of rapamycin in rabbit eyes. Arq Bras Oftalmol. 2009;72(1):18-22.

14. Fauser S, Kalbacher H, Alteheld N, Koizumi K, Krohne TU, Joussen AM. Pharmacokinetics and safety of intravitreally delivered etanercept. Graefes Arch Clin Exp Ophthalmol. 2004;242(7):582-6.

15. Giansanti F, Ramazzotti M, Vannozzi L, Rapizzi E, Fiore T, laccheri B, et al. A pilot study on ocular safety of intravitreal infliximab in a rabbit model. Invest Ophthalmol Vis Sci. 2008;49(3):1151-6.

16. Manzano RP, Peyman GA, Carvounis PE, Kivilcim M, Khan P, Chevez-Barrios P, Takahashi W. Ocular toxicity of intravitreous adalimumab (Humira) in the rabbit. Graefes Arch Clin Exp Ophthalmol. 2008;246(6):907-11.

17. Kitzmann AS, Pulido JS, Mohney BG, Baratz KH, Grube T, Marler RJ, et al. Intraocular use of rituximab. Eye (Lond). 2007;21(12):1524-7. Comment in Eye (Lond). 2007;21(12): $1453-4$

18. Penha FM, Rodrigues EB, Maia M, Furlani BA, Regatieri C, Melo GB, et al. Retinal and ocular toxicity in ocular application of drugs and chemicals--part Il: retinal toxicity of current and new drugs. Ophthalmic Res. 2010;44(4):205-24.

19. Manzano RP, Peyman GA, Carvounis PE, Damico FM, Aguiar RG, loshimoto GL, et al. Toxicity of high-dose intravitreal adalimumab (Humira) in the rabbit. J Ocul Pharmacol Ther. 2011;27(4):327-31.

20. Faure JP. Autoimmunity and the retina. Curr Top Eye Res. 1980;2:215-302.

21. Gery I, Mochizuki M, Nussenblat RB. Retinal specific antigens and the immunopathologic process they provoke. Prog Retin Res. 1986;5:75-109.

22. Caspi RR, Roberg FG, Chan CC, Wiggert B, Chader GJ, Rozenszajn LA, et al. A new model of autoimmune disease. Experimental autoimmune uveoretinitis induced in mice with two different retinal antigens. J Immunol. 1988;140(5):1490-5.

23. Chader GJ. Interphotoreceptor retinoid-binding protein (IRBP): a model protein for molecular biological and clinically relevant studies. Friedenwald lecture. Invest Ophthalmol Vis Sci. 1989;30(1):7-22.

24. Tang J, Zhu W, Silver PB, Su SB, Chan CC, Caspi RR. Autoimmune uveitis elicited with antigen-pulsed dendritic cells has a distinct clinical signature and is driven by unique effector mechanisms: initial encounter with autoantigen defines disease phenotype. J Immunol. 2007;178(9):5578-87

25. de Smet MD, Chan CC. Regulation of ocular inflammation - what experimental and human studies have taught us. Prog Retin Eye Res. 2011;20(6):761-97.

26. de Kozak Y, Sakai J, Thillaye B, Faure JP. S antigen-induced experimental autoimmune uveo-retinitis in rats. Curr Eye Res. 1981;1(6):327-37.

27. Vallochi AL, Todokoro CE, Rizzo LV. Noções gerais de imunologia. In: Orefice F, editor. Uveíte clínica e cirúrgica. 2a ed. Rio de Janeiro: Cultura Médica; 2005. p.61-9.

28. Roberge FG, Loberboum-Galski H, Le Hoang P, de Smet M, Chan CC, Fitzgerald D, Pastan I. Selective immunosuppression of activated T cells with the chimeric toxin IL-2-PE40. Inhibition of experimental autoimmune uveoretinitis. J Immunol. 1989; 143(11):3498-502.

29. Nussenblatt RB, Kuwabara T, de Monasterio FM, Wacker WB. S-antigen uveitis in primates. A new model for human disease. Arch Ophthalmol. 1981;99(6):1090-2.

30. Gregerson DS, Fling SP, Obritsch CF, Merreyman CF, Donoso LA. A new perspective of S-antigen from immunochemical analysis. Curr Eye Res. 1990;9 Suppl:145-53.

31. Yamaki K, Tsuda M, Shinohara T. The sequence of human retinal S-antigen reveals similarities with alpha-transducin. FEBS Lett. 1988;234(1):39-43. Erratum in FEBS Lett 1988;236(2):507

32. Lerner MP, Donoso LA, Nordquist RE, Cunningham MW. Immunological mimicry between retinal S-antigen and group A streptococcal M proteins. Autoimmunity. 1995;22(2):95-106

33. Pepperberg DR, Okajima TL, Ripps H, Chader GJ, Wiggert B. Functional properties of interphotoreceptor retinoid-binding protein. Photochem Photobiol. 1991;54(6): 1057-60.
34. Wiggert B, Kutty G, Long KO, Inouye L, Gery I, Chader GJ, Aguirre GD. Interphotoreceptor retinoid-binding protein (IRBP) in progressive rod-cone degeneration (prcd) - biochemical, immunocytochemical and immunologic studies. Exp Eye Res. 1991 53(3):389-98

35. Lipham WJ, Sanui H, Redmond TM, Wiggert B, de Smet MD, Chader GJ, Gery I. Immunological features of synthetic peptides derived from the retinal protein IRBP. differences between immunodominant and non-dominant peptides. Curr Eye Res. 1990;9(1):95-8.

36. Gery I, Wiggert B, Redmond TM, Kuwabara T, Crawford MA, Vistica BP, Chader GJ. Uveoretinitis and pinealitis induced by immunization with interphotoreceptor retinoid-binding protein. Invest Ophthalmol Vis Sci. 1986;27(8):1296-300

37. Hirose S, Wiggert B, Redmond TM, Kuwabara T, Nussenblatt RB, Chader GJ, Gery I. Uveitis induced in primates by IRBP: humoral and cellular immune responses. Exp Eye Res. 1987:45(5):695-702.

38. Eisenfeld AJ, Bunt-Milam AH, Saari JC. Uveoretinitis in rabbits following immunization with interphotoreceptor retinoid-binding protein. Exp Eye Res. 1987:44(3):425-38.

39. Vistica BP, Usui M, Kuwabara T, Wiggert $B$, Lee L, Redmond TM, et al. IRBP from bovine retina is poorly uveitogenic in guinea pigs and is identical to A-antigen. Curr Eye Res. 1987:6(3):409-17.

40. Adamus G, Chan CC. Experimental autoimmune uveitides: multiple antigens, diverse diseases. Int Rev Immunol. 2002;21(2-3):209-29.

41. Donoso LA, Merryman CF, Sery TW, Vrabec T, Arbizo V, Fong SL. Human IRBP: characterization of uveitopathogenic sites. Curr Eye Res. 1988;7(11):1087-95.

42. Kotake S, Redmond B, Wiggert B, Vistica B, Sanui H, Chader GJ, Gery I. Unusual immunologic properties of the uveitogenic interphotoreceptor retinoid-binding protein-derived peptide R23. Invest Ophthalmol Vis Sci. 1991:32(7):2058-64.

43. Kozhich AT, Kawano Y, Egwuagu CE, Caspi RR, Maturi RK, Berzofsky JA, Gery I. A pathogenic autoimmune process targeted at a surrogate epitope. J Exp Med. 1994; 180(1):133-40

44. Borst DE, Redmond TM, Elser JE, Gonda MA, Wiggert B, Chader GJ, Nickerson JM Interphotoreceptor retinoid-biding protein. Gene characterization, protein repeat structure, and its evolution. J Biol Chem. 1989:264(2):1115-23

45. Fong SL, Fong WB, Morris TA, Kedzie KM, Bridges CD. Characterization and comparative structural features of the gene for human interstitial retinol-binding protein. J Biol Chem. 1990;265(7):3648-53.

46. Silver PB, Rizzo LV, Chan CC, Donoso LA, Wiggert B, Caspi RR. Identification of a major pathogenic epitope in the human IRBP molecule recognized by mice of the $\mathrm{H}-2 \mathrm{r}$ haplotype. Invest Ophthalmol Vis Sci. 1995;36(5):946-54

47. Avichezer D, Silver PB, Chan CC, Wiggert B, Caspi RR. Identification of a new epitope of human IRBP that induces autoimmune uveoretinitis in mice of the $\mathrm{H}-2 \mathrm{~b}$ haplotype. Invest Ophthalmol Vis Sci. 2000:41(1):127-31.

48. Cortes LM, Mattapallil MJ, Silver PB, Donoso LA, Liou Gl, Zhu W, et al. Repertoire analysis and new pathogenic epitopes of IRBP in C57BL/6 $(\mathrm{H}-2 \mathrm{~b})$ and B10.RIII $(\mathrm{H}-2 \mathrm{r})$ mice. Invest Ophthalmol Vis Sci. 2008:49(5):1946-56.

49. Caspi RR, Silver PB, Luger D, Tang J, Cortes LM, Pennesi G, et al. Mouse models of experimental autoimmune uveitis. Ophthalmic Res. 2008;40(3-4):169-74. Review.

50. Broekhuyse RM, Kuhlmann ED, Winkens HJ. Experimental autoimmune anterior uveitis (EAAU). II. Dose-dependent induction and adoptive transfer using a melaninbound antigen of the retinal pigment epithelium. Exp Eye Res. 1992:55(3):401-11.

51. Bora NS, Kim MC, Kabeer NH, Simpson SC, Tandhasetti MT, Cirrito TP, et al. Experimental autoimmune anterior uveitis. Induction with melanin-associated antigen from the iris and ciliary body. Invest Ophthalmol Vis Sci. 1995;36(6):1056-66.

52. Matteson DM, Shen DF, Chan CC. Inhibition of experimental melanin protein-induced uveitis (EMIU) by targeting nitric oxide via phosphatidylcholine-specific phospholipase C. J Autoimmun. 1999;13(2):197-204.

53. Broekhuyse RM, Kuhlmann ED, Winkens HJ. Experimental autoimmune anterior uveitis (EAAU): induction by melanin antigen and suppression by various treatments. Pigment Cell Res. 1993;6(1):1-6.

54. Li Q, Sun B, Matteson DM, O'Brien TP, Chan CC. Cytokines and apoptotic molecules in experimental melanin-protein induced uveitis (EMIU) and experimental autoimmune uveoretinitis (EAU). Autoimmunity. 1999;30(3):171-82.

55. Chan CC, Hikita N, Dastgheib K, Whitcup SM, Gery I, Nussenblatt RB. Experimenta melanin-protein-induced uveitis in the Lewis rat. Immunopathologic processes. Ophthalmology. 1994;101(7):1275-80.

56. Yamaki K, Kondo I, Nakamura H, Miyano M, Konno S, Sakuragi S. Ocular and extraocular inflammation induced by immunization of tyrosinase related protein 1 and 2 in Lewis rats. Exp Eye Res. 2000;71(4):361-9.

57. Yamaki K, Gocho K, Hayakawa K, Kondo I, Sakuragi S. Tyrosinase family proteins are antigens specific to Vogt-Koyanagi-Harada disease. J Immunol. 2000;165(12):7323-9.

58. Damico FM, Cunha-Neto E, Goldberg AC, Iwai LK, Marin ML, Hammer J, et al. T-cell recognition and cytokine profile induced by melanocyte epitopes in patients with HLA-DRB1*0405-positive and -negative Vogt-Koyanagi-Harada uveitis. Invest Ophthalmol Vis Sci. 2005;46(7):2465-71.

59. Buenafe AC, Offner $H$, Machnicki M, Elerding $H$, Adlard $K$, Jacobs $R$, et al. EAE TCR motifs and antigen recognition in myelin basic protein-induced anterior uveitis in Lewis rats. J Immunol. 1998;161(4):2052-9. 
60. Adamus G, Amundson D, Vainiene M, Ariail K, Machnicki M, Weinberg A, Offner H. Myelin basic protein specific T-helper cells induce experimental anterior uveitis. Neurosci Res. 1996;44(6):513-8

61. Shikishima K, Lee WR, Behan WM, Foulds WS. Uveitis and retinal vasculitis in acute experimental allergic encephalomyelitis in the Lewis rat: an ultrastructural study. Exp Eye Res. 1993;56(2):167-75. Comment in Exp Eye Res. 1993;57(6):791-2.

62. Adamus G, Manczak M, Sugden B, Arendt A, Hargrave PA, Offner H. Epitope recognition and $T$ cell receptors in recurrent autoimmune anterior uveitis in Lewis rats immunized with myelin basic protein. J Neuroimmunol. 2000;108(1-2):122-30.

63. Adamus G, Sugden B, Arendt A, Hargrave PA. Importance of cryptic myelin basic protein epitopes in the pathogenicity of acute and recurrent anterior uveitis associated with EAE. J Neuroimmunol. 2001;113(2):212-9.

64. Rosenbaum JT, McDevitt HO, Guss RB, Egbert PR. Endotoxin-induced uveitis in rats as a model for human disease. Nature. 1980;286(5773):611-3.

65. Bhattacherjee $P$, Parke $A$. The reduction of inflammatory responses in polysaccharide-tolerant eyes. Am J Pathol. 1986;122(2):268-76.
66. Petty RE, Johnston W, McCormick AQ, Hunt DW, Rootman J, Rollins DF. Uveitis and arthritis induced by adjuvant: clinical, immunologic and histologic characteristics. J Rheumatol. 1989;16(4):499-505.

67. Fleisher LN, Ferrel JB, McGahan MC. Synergistic uveitic effects of tumor necrosis factor-alpha and interleukin-1 beta. Invest Ophthalmol Vis Sci. 1992:33(7):2120-7.

68. Hoekzema R, Verhagen C, van Haren M, Kijlstra A. Endotoxin-induced uveitis in the rat. The significance of intraocular interleukin-6. Invest Ophthalmol Vis Sci. 1992:33(3):532-9.

69. Taneja V, David CS. HLA class II transgenic mice as models of human diseases. Immunol Rev. 1999;169:67-79.

70. Pennesi G, Mattapallil MJ, Sun SH, Avichezer D, Silver PB, Karabekian Z, et al. A humanized model of experimental autoimmune uveitis in HLA class II transgenic mice. J Clin Invest. 2003;111(8):1171-80.

71. Tang J, Zhu W, Silver PB, Su SB, Chan CC, Caspi RR. Autoimmune uveitis elicited with antigen-pulsed dendritic cells has a distinct clinical signature and is driven by unique effector mechanisms: initial encounter with autoantigen defines disease phenotype. J Immunol. 2007:178(9):5578-87.

\section{Simpósio de Retina 20/20 do Banco de Olhos de Sorocaba}

25 a 27 de outubro de 2012

Banco de Olhos de Sorocaba - Sorocaba (SP) 